\title{
Health communication patterns of clean and healthy behavior in islamic Boarding School
}

\author{
Uud Wahyudin ${ }^{1}$, Kismiyati El Karimah ${ }^{2}$ \\ ${ }^{1,2}$ Universitas Padjadjaran, Bandung Indonesia
}

\begin{abstract}
The information received by Santries from various sources regarding infectious diseases in Pondok Pesantren's environment is still confusing, which causes the Santries to be confused about finding reliable sources of information for their own health. They have sought this information through various sources. The purpose of this study is to determine who is the primary source of dissemination of health communication information related to Clean and Healthy Behavior and the health communication process within the Islamic boarding school in Sukabumi Regency, West Java, Indonesia. This study used a qualitative research method; then, the final results presented the health communication pattern among Islamic Boarding School in Sukabumi Regency. A case study approach was used in this study. The unavailability of updated, relevant data shows that the Central Government is still not actively moving towards the success of the PHBS Program at the national level in general and the education level of Islamic boarding schools in general. The difference between the provisions of the central government and the teachings of the Islamic religion that is applied in the Islamic Boarding School environment is one of the obstacles to implementing PHBS at the education level. The health information available in the mass media cannot be used by Santries to obtain information related to health. This research concludes that health information from Kyai's teachings are the primary sources of health information in the Pesantren environment, supported by health information written in the Al- Quran and Al-Hadiths. Santries can receive health information outside the Pesantren environment through medical personnel, mass media, and information from the school. Suggestions from this research are PHBS counseling for Kyai and Santries according to national health standards under the guidance and supervision of the Ministry of Health.
\end{abstract}

Keywords: Health communication; islamic boarding school; health communication patterns; health information source; clean and healthy lifestyle

\section{Pola komunikasi kesehatan perilaku hidup bersih dan sehat di Pondok Pesantren}

\begin{abstract}
ABSTRAK
Informasi yang diterima santri dari berbagai sumber mengenai penyakit menular di lingkungan Pondok Pesantren masih simpang siur sehingga menyebabkan Santri bingung mencari sumber informasi yang dapat dipercaya untuk kesehatannya sendiri. Mereka telah mencari informasi ini melalui berbagai sumber. Tujuan penelitian ini adalah untuk mengetahui siapa sumber utama penyebaran informasi komunikasi kesehatan terkait Perilaku Hidup Bersih dan Sehat (PHBS) dan proses komunikasi kesehatan di lingkungan pondok pesantren di Kabupaten Sukabumi, Jawa Barat, Indonesia. Penelitian ini menggunakan metode penelitian kualitatif, kemudian hasil akhir mempresentasikan pola komunikasi kesehatan di kalangan Pondok Pesantren di Kabupaten Sukabumi. Pendekatan studi kasus digunakan dalam penelitian ini. Tidak tersedianya data relevan yang terupdate menunjukkan bahwa Pemerintah Pusat masih belum aktif bergerak menuju keberhasilan Program PHBS di tingkat nasional pada umumnya, dan tingkat pendidikan pesantren pada umumnya. Perbedaan antara ketentuan pemerintah pusat dengan ajaran agama Islam yang diterapkan di lingkungan Pondok Pesantren menjadi salah satu kendala pelaksanaan PHBS di tingkat pendidikan. Informasi kesehatan yang ada di media massa tidak dapat dimanfaatkan oleh Santries untuk memperoleh informasi terkait kesehatan. Kesimpulan dari penelitian ini adalah informasi kesehatan dari ajaran Kyai merupakan sumber utama informasi kesehatan di lingkungan Pesantren, didukung oleh informasi kesehatan yang tertulis dalam Al-Quran dan Al-Hadits. Informasi kesehatan yang berasal dari luar lingkungan Pesantren dapat diterima oleh Santri melalui tenaga medis, media massa, dan informasi dari pihak sekolah. Saran dari penelitian ini adalah penyuluhan PHBS bagi Kyai dan Santri sesuai standar kesehatan nasional di bawah pembinaan dan pengawasan Kementerian Kesehatan.
\end{abstract}

Kata-Kata kunci: Komunikasi kesehatan; pondok pesantren; pola komunikasi kesehatan; Sumber informasi kesehatan; gaya hidup bersih dan sehat

Korespondensi: Dr. Uud Wahyudin, S.Sos., M.Si. Universitas Padjadjaran. Jl. Raya Bandung Sumedang KM.21, Sumedang, Jawa Barat 45363.Email:uudwahyudin@unpad.ac.id 


\section{INTRODUCTION}

One of the health development missions in Indonesia is to mobilize and empower the community to adopt a Clean and Healthy Life Behavior (after this written PHBS/Perilaku Hidup Bersih dan Sehat). According to the PHBS (Indonesia, 2011), PHBS is a set of behaviors that are practiced based on awareness as a result of learning, which makes a person, family, group, or community able to help themselves (independently) in the health sector and play an active role in realizing public health. The main goal of the PHBS movement is to improve the quality of health through a process of awareness which is the beginning of the contribution of individuals in living clean and healthy daily life behaviors.

The Ministry of Health of the Indonesia Republic stated that in 2017, Indonesia was in the third position of the infectious disease spread cases caused by unsanitary and healthy living habits after India and China. One of the efforts made by the Central Government to implement PHBS is to routinely conduct public health screening, which generally starts from the environmental structure of Islamic boarding schools, Indonesian National MilitaryIndonesian National Police Departement, dormitories, all prisons in the country, and the generalpublic.

PHBS consists of several indicators, namely washing hands with running water and using soap, throwing garbage in its place, and so on, but this study limits itself only to the application of PHBS in educational institutions in Islamic boarding schools (after this written as Pondok Pesantren). The importance of school health is contained in Health Law no. 36 of 2009 article 79, which reads School health is held to improve the ability of students (after this written as Santries) to live healthy in a healthy environment so that Santries learn, grow and develop harmoniously and as high as possible become quality human resources.

One of the boarding-based educational institutions widely scattered in Indonesia is Pondok Pesantren, where Santries live and study in a boarding school environment which isusually in the form of an Education complex under the guidance of a teacher (after this written as Kyai). Pondok Pesantren are in great demand in Indonesia because they have a unique way of education in building a balanced life between the world and the hereafter. As the province with the most extensive distribution map of Pondok Pesantren in Indonesia, West Java has participated in campaigning for the PHBS in public school settings and Pondok Pesantren in particular based on guidelines from the Ministry of Health of the Republic of Indonesia. The West Java Provincial Health Office believes educational institutions are strategically positioned to promote and instill PHBS values and a healthy lifestyle. School Santries are also potential agents of change to promote PHBS in the school, family, and community environment.

Disease transmission in boarding education institutions is frequent, especially in Salafiah Pesantren, synonymous with traditional (classical) pesantren. Disease transmission among Santries and teachers in a dormitory environment spreads faster than other educational institutions. The high intensity of repeated interactions between individuals and shared facilities in the living and learning environment becomes a difficult obstacle to breaking the disease spread chain. Thus, various unclean living behaviors are still found in traditional Islamic boarding school (Wahyudin \& Arifin, 2015).

One of the infectious diseases caused by unsanitary life behavior and often attacks Santries in Pondok Pesantren, especially Salafiah Pesantren, primarily located in rural areas such as in Sukabumi Regency, is a scabies skin disease which is better known as "Budug" in Indonesia. Scabies in Pondok Pesantren is considered a "compulsory" disease suffered by Santries until the birth of the Santries label "Budug" which means Santries, who is filthy, dirty, and shabby in appearance. A bad stigma has long been attached to the Santries of the Salafiah Pesantren, who adhere to an effortless and straightforward lifestyle.

The main objective of the Salafiah Pesantren is to produce religious experts with a straightforward worldly lifestyle. The buildings of the Salafiah Pesantren are generally elementary, with poor sanitation systems, lack of natural lighting, and neglected indoor air ventilation. Clean water for bathing, washing, and latrines is made simple without thinking about waste disposal and used jointly by all residents. Healthy and balanced food is 
also put aside by the system. The presence of infectious diseases among Salafiah Pesantren residents, especially Santries, is considered very reasonable and familiar to the extent of misunderstanding news circulating on social media which says that the infectious disease experienced by Santries is an attempt to detox the body as part of self-purification so that they can absorb more of the religious life in Pondok Pesantren.

Santries have sought this information through various sources, both health workers/ Public health centers, through interpersonal channels such as discussions with Kyai/Ustadz, senior Santries, school authorities, as well as the books they have studied themselves in Pesantren, as well as through mass media and social media. The implementation of PHBS in Pondok Pesantren is not yet ideal, especially in the Sukabumi Regency area, which contradicts what is taught based on Islamic education.

The purpose of this study is to determine who is the primary source of dissemination of health communication information related to Clean and Healthy Behavior, PHBS Program, and the health communication process within Pondok Pesantren in Sukabumi Regency, West Java,Indonesia. According to (Babak Moeini, 2016), simple approaches such as health information can be helpful to increase the level of education and health care for people. However, experience hasshown that the addition of communication strategies and the use of health education and health promotion specialists to plan and design effective training programs tailored to the target groups is needed in this area.

This study has implications as a guideline for the Central and Local Governments to make Kyai as health cadres and supervise the implementation of PHBS in Pondok Pesantren, considering that the Santries of Salafiah Pesantren has very high trust and honor for their Kyais. According to the research results by (Wahyudin, 2013), Kyai must guide people in developing healthy, mature attitudes and a solid determination to act together strategically tatch up with lags.

PHBS counseling for Kyai and Santries according to national health standards under the guidance and supervision of the Ministry of Health will significantly encourage the implementation of clean and healthy living habits in the community, especially in boarding schools that have a high level of spread of infectious diseases. This study can also be used as an evaluation by themanagement of Pondok Pesantren in implementing a healthy lifestyle for all residents. Exemplary PHBS implementation in schools and Pondok Pesantren will have good implications for improving the health of the Indonesian people. Academically, this study can enrich the study of health communication with a focus on school health information sources.

\section{RESEARCH METHODS}

This article used qualitative methods that allowed the researcher to interpret and explaina phenomenon holistically by using words without depending on a number. According to (Lexy J.Moleong, 2017) qualitative methodology is a research procedure that produces descriptive data in written or oral words from the people and the observed behavior. In this article, the author used a case study approach because it is considered appropriate and suitable with the phenomenon, where the implementation of PHBS in PondokPesantren in rural areas of the Sukabumi Regency is still far from ideal. The local government claims that it is sufficient to educate and socialize the PHBS implementation in Pondok Pesantren. However, many Santries in rural areas still do not understand or even implement the PHBS Program from the Ministry of Health of the Republicof Indonesia.

The informants in this article were chosen by the purposive sampling technique to obtain the data and answer the objectives. Secondary data was obtained from stakeholders like West Java Provincial Health Office and Sukabumi District Health Office. The key informants in this study are senior Santries living in the Pondok Pesantren in the rural areas of the Sukabumi Regency. These characteristics were chosen so that informants could compare their life behavior before living in the Pesantren and while living in the Pesantren environment and could provide a comprehensive explanation of the culture of life in the boarding school. Several criteria for selecting informants in this study include (1) Ten senior Santries who lived and studied formal education inside or outside Pondok Pesantren for at least one year and had 
suffered from infectious diseases in the Pondok Pesantren environment. (2) Five senior Santries who have consciously searched for health information have become health cadres or participated in disseminating healthinformation communications within the Pondok Pesantren.

(3) Two Kyai in the pesantren environment.

(4) Two policymakers and authorities for the PHBS Program in the school environment and the general public, both at the central and regional government levels. (5) Two medical and health personnel directly involved in the implementation and supervision of PHBS in the Sukabumi Regency.

Data collection was carried out by nonparticipatory observation using the sense of sight of conditions, situations, the process of activities that occur at Pondok Pesantren, and especially observing how the Santries behave while inserting open and in-depth interviews with informants in the Pondok Pesantren area, as well as collecting supporting documents both from the Pondok Pesantren repository, and related government agencies.

Data analysis was performed by reducing the data, sorting, and selecting relevant data/ information. Furthermore, the display data in the form of descriptions data or information about the context focuses and answers to the research questions posed in a narrative. Based on the narrative description data, the researcher formulated the constructs conveyed by the informants to formulate relevant concepts. The final stage is drawing conclusions and verification by drawing objective conclusions based on the subjectivity of the data provided by the research informants and the records of participating observations. The three stages of data analysis are interconnected and continue throughout the research.

\section{RESULTS AND DISCUSSION}

The incidence and prevalence of infectious diseases in Indonesia are still very high, especially in the Pesantren community because Santries live together with a group of people who have different levels of concern, understanding, and application of personal hygiene in the boarding school environment. In addition, PHBS, especially personal hygiene, generally received less attention from Santries.
Ridwan, A.R., Sahrudin, S., Ibrahim, K. (2017) found that Pondok Pesantren in Indonesia grows in slum environments, dirty baths and toilets, humid environments, and poor sanitation. The same unhealthy lifestyle was carried out by Santries in this study, where they live in a humid environment, lack of ventilation and sanitation systems which are far below sufficient.

Based on the results of a similar study at Pondok Pesantren in Kendari City (2017), the low level of personal hygiene for Santries in the Islamic boarding school can be seen from the habit of some Santries showering only once a day, taking turns using the same towels, often changing clothes with fellow Santries, using tools. Sleeping alternately (covers, pillows, bolsters, and blankets), and in front of the rooms the Santries look messy and dirty, books, clothes are not neatly arranged, food waste is also only collected in front of the room, not cleaned immediately, and pile up or hang dirty clothes for weeks without washing it.

One of the poor condition of students and TIBS's environment is related to low health literacy and limited availability of health information sources (Bajari, Wahyudin, \& Erlandia, 2019). It was also found that Santries at Pondok Pesantren in the rural areas of Sukabumi Regency usually sleep by placing a mattress on the floor as their bed, and some are just wearing a mat. Before carrying out their routine activities, they cleaned the mattress and piled the sleeping mats on the edge of the Santries 'bedrooms, mixing with other Santries' sleeping tools.

This study found several reliable sources of health information for Santries in Pondok Pesantren in Sukabumi RegencyWest Java, which was sorted from primary health information sources to additional health information sources. The sources of health information and the PHBS Program cannot stand alone and will always be related to one another. As said by (Schiavo, 2015) that for health communication, the first words that come to mind are 'increased collaboration.' Despite the progress on platforms and support for crosssectoral communication efforts (for example, across the fields of public health, healthcare, community development, global health, science, and others), too many partnerships and exchanges are stillrelying solely on the goodwill and hard work of the professionals who pursue 


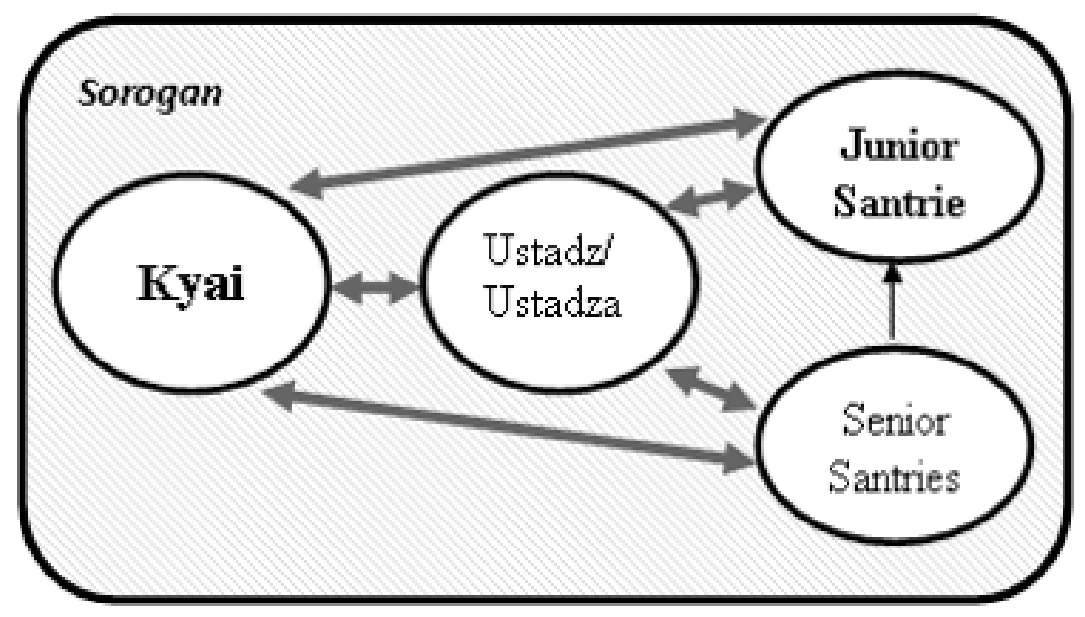

Source: Study Result, 2014

Figure 1 Health Communication Patterns of Hygiene \& Healthy Behavior in Sorogan Teaching and Learning Settings in Islamic Boarding School

them. Therefore, health communication can be said as a systematic communication effort to improve the quality of human health (Wahyudin, 2018). Thus, health communication is a multidisciplinary approach to sharing health information (Mulyana et al., 2018). In contrast, the successful implementation of the PHBS program and achieving the goal of equal distribution of health for the Indonesian people in general and school students, particularly, require serious cooperation from many parties.

The kyai or teacher is usually the owner of Pondok Pesantren and the internal regulator and is considered a religious figure by the surrounding community that his followers always adhere to his advice and suggestions. Therefore, the Kyai is considered to have the ability to convey his opinion. In highlighting the position of Kyai as a community guide.

The doctrine of the Kyai in teaching health and hygiene at environment of pesantren and those who are not (Bajari, Wahyudin, Koswara, et al., 2019). The Kyai in their role as communicators of PHBS in boarding schools which in turn this image is expected to be used as a reference for health decision makers in conducting PHBS communication campaign in educational institutions in order to become more persuasive health communicators (Wahyudin \& Setiaman, 2019).

The result shows that the role of Kyai and Ustadz in the socialization of PHBS in rural Pesantren is related to the characteristics possessed by Kyai or Ustadz. In Islam, all forms of information originating from Kyai and Ustadz are considered reliable sources and should not be refuted or denied. So high is the respect of the Santries for the Kyai and their Ustadz that they put enormous trust in every Kyai's words and behavior as aguide and role model as they have to behave in everyday life. The character of the Kyai in society is also supported by his function as a teacher to guide the people in their daily life so that all their actions follow the teachings of Islam.

Kyai is required to have the ability to explain to the public the main characteristicsof the global picture of modern public health following Islamic teachings; what are the essential characteristics of information processing systems; what is the position of science in the education system; how the economic system should be developed; what is the system that people must develop.

This study indicates that the first source of health information for Santries is the Kyai as the essential element of a Pesantren and a professor in Islamic teachings. Being a Kyai means that person must have a healthy body and soul. He must be physically and mentally prepared to broadcast the teachings of Islam. In this study, three patterns of health and hygiene information delivery in the Pondok Pesantren is usually carried out by Kyai to Santries during The Sorogan setting, group health communication during The Bandongan setting or the "deliberation class," and organizational health communication when discussing health 


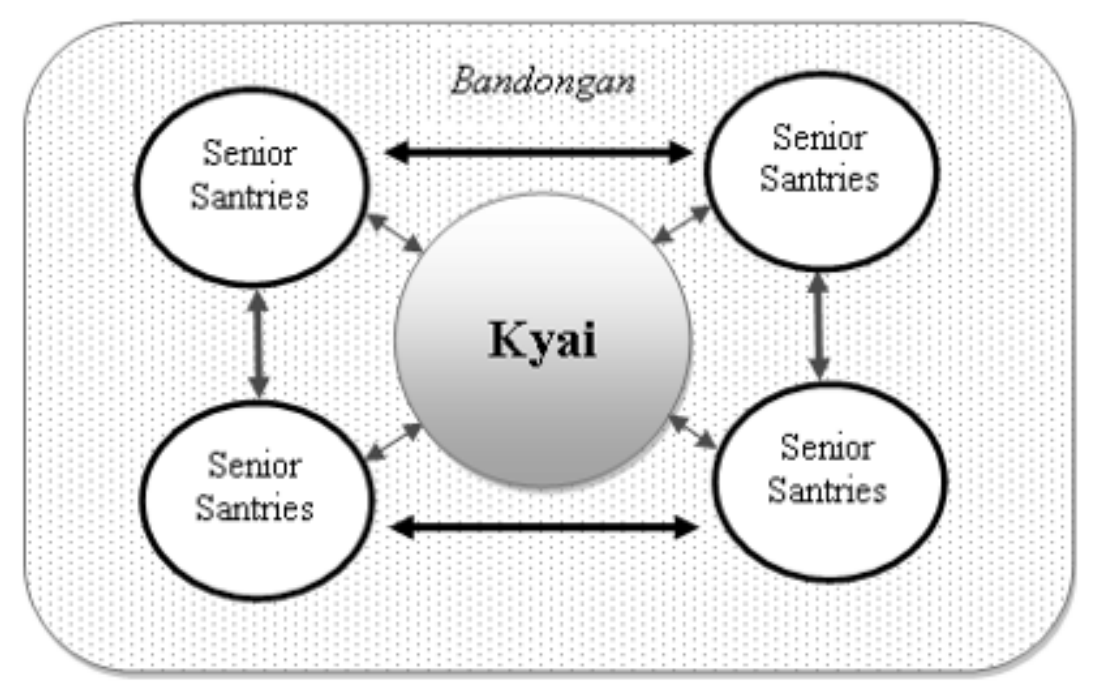

Source: Study Result, 2014

Figure 2 Health Communication Patterns of Hygiene \& Healthy Behavior in Bandongan Teaching and Learning Settings in Islamic Boarding School

activities or programs to be carried out.

Kyai, Ustadz, and Senior Santries have a role in providing health and hygiene information to Junior Santries during the Sorogan setting. Interpersonal health communication is thickly applied in the Sorogan learning system, occurs directly between the Kyai to tutor (after this written as Ustadz), which is then forwarded back to the Santries and direct communication between the Kyai and the Santries. The following illustrates thepattern of health communication in the context of Sorogan figure 1.

Group health communication is applied in the Bandongan learning or weton systems. In this system, a group of Santries (between 5-20 Santries) listens to an Ustadz who reads, translates, explains, and often reviews Islamic books in Arabic. This particular group of Santries is called the "deliberation class" (seminar group). Each student listens to hisown book and notes (both meaning and description) of difficult words or thoughts. Santries inform each other about health and sometimes share them in groups. The Bandongan system class group is called halaqah, which means the circle of Santries, or groups of Santries who study under the guidance of a teacher (Ustadz). The role of the Kyai is necessary for group health communication and acts as a "translator" in the health communication process. It means that recruiting health cadres among Santries requires consideration of the Kyai as an opinion leader. Health communication in the Bandongan setting occurs between Kyai and a group of Santries consisting of more than one person in the same educational level, such as health discussions between groups of senior Santries and Kyai. Usually, health information in a Bandongan setting is done in the form of a twoway group discussion about a particular health issue. The pattern of health communication in a Bandongan setting is depicted as follows figure 2.

In this era of digitalization, both Kyai and Santries must be literate in technology, both website, and application-based. Kyai, in this study, looks for digital-based information sources such as figures, videos, pictures, or narrative audio recording as their learning aids to be conveyed to Santries, and Santries can use existing technology to find information about health and personal hygiene. This method applied for low and adequate health literacy Santries in Pondok Pesantren. A similar study by (Moran, MB, Chatterjee, JS., Frank, LB., Murphy, ST., Baezconden-Garbanati, LA., 2016) found that the narrative such as in film worked equally well for individuals with low and adequate healthliteracy and was considered to be more acceptable than the non-narrative film by both groups. These findings have important implications for health communication policy and recommendations.

In addition, Kyai and Ustadz apply what is 
taught in the Al-Quran and Al-Hadith regarding the method of often giving interrogative sentences before discussing a topic to help Santries in a position to be ready to receive and process information. This question is essential to make the Santries more focused on thinking about something. Kyai and ustdaz convey information from the positive and negative sides so that the Santries can betterunderstand the limits of the information provided.

The holy books studied in Pondok Pesantren include concise texts to texts consistingof thick volumes regarding hadith, tafsir, fiqh, fiqh proposals, and tasawuf. The similarity of the books taught and the teaching system resulted in the homogeneity of life views, culture, and religious practices among Kyai and Santries. In reality, the traditional Pondok Pesantren education system, which is usually considered very "static" in following the Sorogan and Bandongan systems in translating classical Islamic books, does not merely talk about form by forgetting the teaching content contained in those books. The Kyai, as readers and translators of the book, read not only the text but also provide personal views (interpretations), both regarding the content and language.

One of how the Al-Quran is taught is by setting an example through the stories of former people in narrative ways. The element of art or beauty of the information conveyed can influence those who receive the information. People are quicker to remember information that catches their attention through narrative storytelling. A similar study by BaezcondeGarbanati, LA., Chatterjee, JS., Frank, LB., dan Murphy, ST. (2014) summarized that narratives might be particularly successful in changing behavior among vulnerable populations, such as those with low income, low education, and low literacy levels, who also tend to be the ones suffering the most significant health disparities.

Several examples of health and personal hygiene information were conveyed by Kyai to Santries at Pondok Pesantren through previous stories as told in the Al-Quran and Al-Hadith, such as the story of Prophet Muhammad SAW, who had prevented transmission of infectious diseases by quarantining the sufferer. Santries use this knowledge to deal with infectious disease incidents in the Pesantren environment in the future. In addition, the book Ta'limu muta'alim (knowledge of morality) teaches about ways to treat diseases. A similar book that teaches the same is the Book of Safinah. Another example of a story that Kyai and Ustadz recounted to Santries is the story of Prophet Ibrahim a.s. when burned, it turns out to be alive and not injured because he read a prayer asking for blessings from Allah SWT. This prayer became known in the boarding school environment as the prayer of Prophet Ibrahim.

Apart from Kyai and books studied in the Pesantren as a source of health and hygiene information, it also comes from health medical personnel. The Santries entrust treatment through health medical personnel known as Mantri to deal with disease attacks. They treat and get information from health care providers about preventing infectious diseases from recurring. Counseling or providing health information from the health nurseincludes counseling on food health, healthy bathing practices, the health of the Pesantren environment, and others.

The latest data released by the West Java Regional Government Health Office is data on health facilities and infrastructure available in 2018 and widely published in 2019. In 2018 there were 2,039 health workers spread across sub-districts in the Sukabumi Regency, experiencing an increase of about 5, 21 percent compared to the previous year, which totaled 1,938 health workers. The number of midwives was the largest, namely 1,113 people or 56.70 percent of the total health workers in the Sukabumi District.

If the Santries have contracted an infectious disease, the primary information they are looking for is information from medical personnel. Medical personnel is responsible for providing education to Santries related to ways to prevent transmission of infectious diseases and maintain personal hygiene. However, Santries used the information from health workers is only limited to medical treatment, not on the implementation of PHBS daily.

Apart from sources of information from health workers/health care providers and doctors, the village midwife also acts as a source of information needed by the Santries. The results of this study in the field indicate that village midwives have a crucial role in disseminating information on PHBS in the Pondok Pesantren. The village midwife is a Public health center midwife who then collaborates with the 


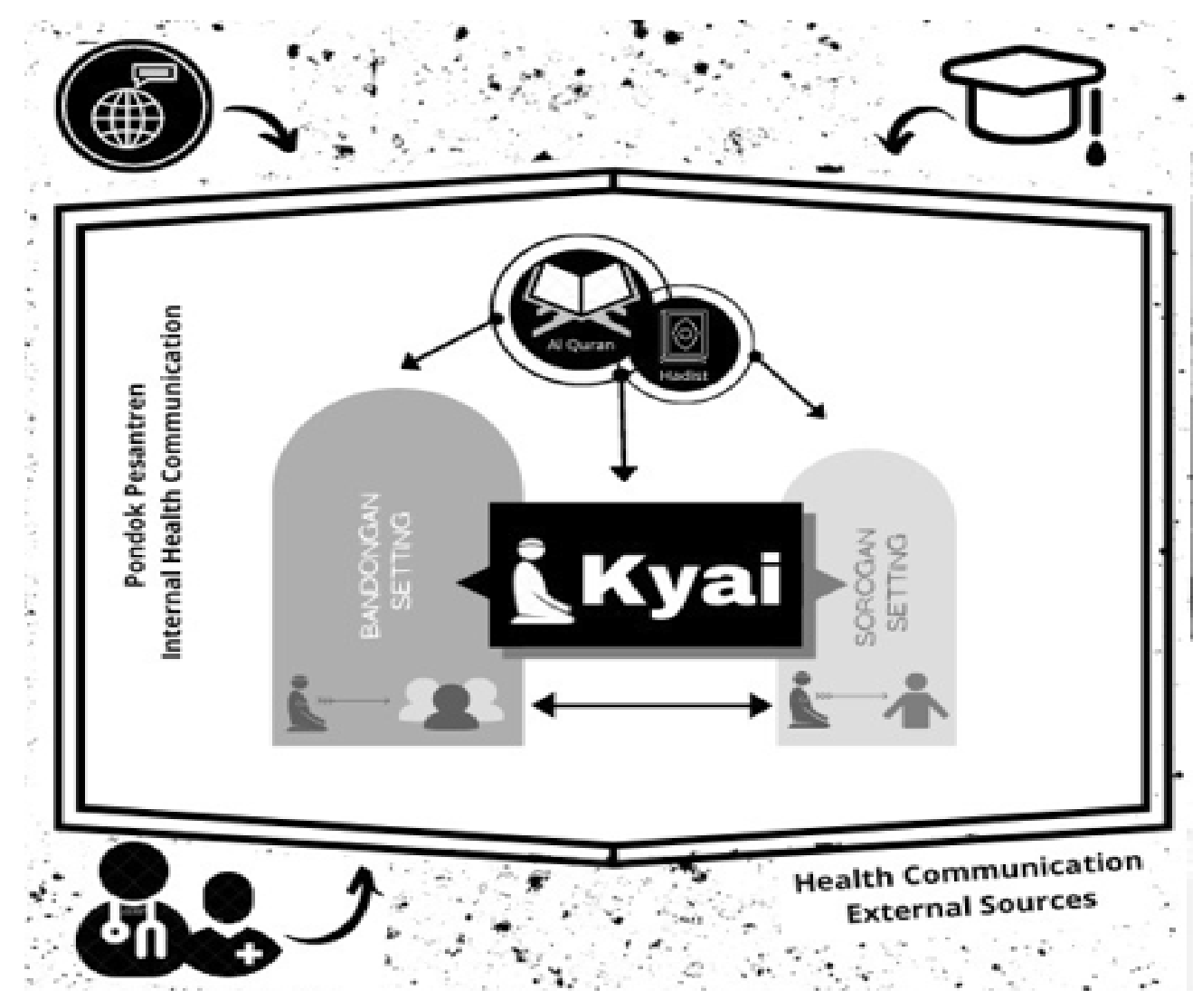

Source: Study Result, 2014

Figure 3 Health Communication Patterns of Hygiene \& Healthy Behavior in Islamic Boarding School

Pesantren to organize Subdistricts Health Departement's activities. The village midwife will periodically come to the Pesantren to carry out Subdistricts Health Departement activities. The presence of the village midwife at the Pesantren encourages Santries to obtain health information. Santrieyats (Female Santries) can become health cadres who assist village midwives in Subdistrict Health Department's activities and other health activities in Pondok Pesantren. As local community members, the Health Cadres are selected and reviewed by the community and can work voluntarily. The role of health cadres in each region is quite large and quite heavy.

Based on the results of the (Estrada-Portales, 2016) research, media advocacy in grassroots organizing and activism health information is an essential strategy to accomplish three main objectives: influence and shape public debate about health information, exert pressure over decision-makers for public health decisions, and, most importantly, strengthen and amplify the community's voice about the application of healthy behavior. Nevertheless, in this study, neither mass media nor social media can rely on the Santries as their primary source of health information.

Findings in the field show that data on the latest health facilities and medical personnel are still limited at both the central and local government levels. The unavailability of up-todate data that the Indonesian people can widely access may result in the inadequacy of the PHBS application from the factual conditions in the field. In addition, the unavailability of the latest relevant data can cause the knowledge held by Government stakeholders to disseminate the PHBS to become obsolete without any refreshment. The unavailability of the latest relevant data shows that the Central Government is still not actively moving towards the success of the PHBS Program at the national level in general and the education level of Pondok Pesantren in general. Another finding from this study is that since 2011, there has never been any re-adjustment of PHBS guidelines in Indonesia, and since 2016, the West Java Provincial Government Health Office has not updated the West Java Provincial Health 
Strategic Plan.

Another finding of this study is that there are contradictory regulations on health regulations by the Central and Local Governments and Islamic teachings that all Pondok Pesantren residents understand. If the Central and Regional Government regulations prohibit Santries with infectious diseases from being sent home and temporarily leaving the boarding school environment, this is intended to prevent more comprehensive transmission of infectious diseases in communities outside the Pondok Pesantren. However, this regulation isdifferent from Islamic teachings in dealing with infectious disease outbreaks. In the Al-Quran, it is told how the Prophet Muhammad SAW separated and quarantined people with infectiousdiseases not to transmit the disease to other people. In the view of Pondok Pesantren, if Santries who suffer from infectious diseases are not separated from other Santries in the sensethat they are sent back to their parents' house until they recover, it is feared that they will infectother Santries who live in the Pondok Pesantren environment. Until now, Pondok Pesantren from city to district levels do not have special health facilities to quarantine Santries or Pesantren's residents who suffer from infectious diseases within the Pesantren area.

This study also found that the mass media, which was suspected as a source of heh information for Santries, was not the primary source. The Santries' limitations in accessing information from the media are limited because they can only access mass media, such as social media, radio stations, newspapers, or television, when there are school or college assignments. The health information available in the mass media has not been used by the Santries to obtaininformation related to health.

However, the information that comes from health workers is perceived differently by the Santries. In addition to information from different health workers, the ability to process information from Santries is also different, causing different understandings. The findings in the field showed that not all Santries, especially those in the Sukabumi Regency Islamic Boarding School, entrusted their health to a medical doctor. Many Santries are more entrusted with their medical treatment by "seeking treatment" to Kyai or Ustadz.Santries from this group believe that prayers from Kyai or
Ustadz are considered more effectivein healing and more blessing for themselves than medical treatment.

Based on the study results, it is known that there are internal and external sources of health communication for Santries and residents of Pondok Pesantren. Figure 3 shows the source of health information for santries. The source of internal information is Kyai as the figure most respected and trusted by the Santries who provides health communication information based on the Al-Quran, Al-Hadith, and makes the Prophet Muhammad's lifestyle a way of life. While the external source of health communication comes fomsocial media, school, medical personal, and health cadres occurred in an irregular and unsustainable period. If described, the following is the process of exchanging health communication within Pondok Pesantren in Sukabumi Regency, West Java, Indonesia.

\section{CONCLUSION}

The Santries at Salafiah Pesantren in Sukabumi Regency are aware of their unclean andunhealthy life habits. However, the Santries who do not understand the PHBS Principles, in the end, consider the culture of being less clean in the Pesantren environment is normal. Meanwhile, Santries, who have a sufficient understanding of the PHBS principles, feel that livingin a boarding school environment that does not implement PHBS is a challenge. Awareness to maintain cleanliness and health comes from reliable sources within the Pesantren and outsidethe Pesantren. Health information from Kyai's teachings is the primary source of health information in the Pesantren environment, supported by health information written in the Al-Quran and Al-Hadiths. Santries can receive health information outside the Pesantren environment through medical personnel, mass media, and information from theschool.

Santries experienced many obstacles in getting information about the prevention and cure of infectious diseases in the Pesantren environment. Health literacy among Santries is still low; it can be seen explicitly from the low basic information-seeking skills. Santries have primarily obtained sources of health information through Kyai/Ustadz, yellow books (Al-Quran without punctuation), and limited 
information from health workers in the village. The Santries are also limited in accessing health information through mass media and social media because their access to mass media is very limited. Santries can only watch television and are allowed to access mobile phones only on Friday or where there are no recitation/study activities.

However, unfortunately, Kyai, as the primary source of health information and the PHBS program in Pondok Pesantren, up until this study was completed, had not received any counseling or socialization regarding the implementation of PHBS according to national health standards. Therefore, local governments must pay more attention to making kyai or community leaders as health cadres under the direct guidance and supervision of the health office so that health education and the PHBS program launched by the government ten years ago can reach the lives of Santries in Pondok Pesantren in rural areas of the Sukabumi Regency.

\section{REFERENCES}

Babak Moeini, S. H. (2016). Factors associated with health literacy and self-care behaviors among Iranian diabetic patients: A crosssectional study. Journal of Communication in Healthcare, 279-287. https://doi.org/10. 1080/17538068.2016.1217968

Baezconde-Garbanati, L. A., Chatterjee, J. S., Frank, L. B., Murphy, S. T., Moran, M. B., Werth, L. N., \& O'Brien, D. (2014). Tamale Lesson: A case study of a narrative health communication intervention. Journal of Communication in Healthcare, 82-92. https://doi.org/10.1179/175380761 4Y.0000000055

Bajari, A., Wahyudin, U., \& Erlandia, D. R. (2019). Kyai vs internet and media the influence of media and the internet in health material learning in traditional islamic boarding schools (tibss) in West Java, Indonesia. Library Philosophy and Practice (e-Journal), 1872-1877. https:// digitalcommons.unl.edu/libphilprac/3011

Bajari, A., Wahyudin, U., Koswara, I., \& Erlandia, D. . (2019). The policy of media and internet access for seeking environment and health information at tradisional islamic education, Indonesia. International Journal of Science and Research (IJSR), 1872-1877. www.ijsr.net. 2319-7064/ Impact Factor (2018):7.426

Estrada-Portales, I. M. (2016). Why Media matters in healthcare advocacy and education. Journal of Communication in Healthcare, 75-77. https://doi.org/10.1080 /17538068.2016.1190589

Indonesia, K. K. (2011). Program Perilaku Hidup Bersih \& Sehat. Indonesia K. K., November. http://promkes.kemkes.go.id/ phbs

Lexy J.Moleong. (2017). Metodologi Penelitian Kualitatif (Edisi Revisi). In PT. Remaja Rosda Karya. PT Remaja Rosdakarya.

Moran, M. B., Frank, L. B., Chatterjee, J. S., Murphy, S. T., \& Baezconde-Garbanati, L. (2016). A pilot test of the acceptability and efficacy of narrative and nonnarrative health education materials in a low health literacy population. Journal of Communication in Healthcare, 40-48. https://doi.org/10.1080/17538068.2015.11 26995

Mulyana, D., Hidayat, D. ., Karlinah, S., Dida, S., Silvana, T., Suryana, A., \& Suminar, J. . (2018). Komunikasi kesehatan, pemikiran dan penelitian. Bandung: Remaja Rosdakarya.

Ridwan, A. R., Sahrudin, \& Ibrahim, K. (2017). Hubungan Pengetahuan, Personal Hygiene, dan Kepadatan Hunian dengan Gejala Penyakit Skabies pada Santri di Pondok Pesantren Darul Muklisin Kota Kendari. Jurnal Ilmiah Mahasiswa Kesehatan Masyarakat, 2(6), 1-8. https://doi.org/ http://dx.doi.org/10.37887/jimkesmas. v2i6.2914

Schiavo, R. (2015). Advancing the field of health communication. Journal of Communication in Healthcare, 8(1), 1-2. https://doi.org/[109.194.216.190

Wahyudin, U. (2013). Faktor-Faktor Karakteristik dan Peranan Kyai dalam Sosialisasi PHBS di Lingkungan Pesantren Perdesaan di Kabupaten Sukabumi, Laporan Penelitian P4D (Hibah Doktor) (Issue Laporan Penelitian P4D (Hibah Doktor). 
Wahyudin, U. (2018). Komunikasi Kesehatan. Unpad Press.

Wahyudin, U., \& Arifin, H. S. (2015). Sosialisasi sanitasi diri dan lingkungan di pesantren salafi melalui pos kesehatan pesantren dalam membentuk sikap santri terhadap sanitasi. Jurnal Kajian
Komunikasi., 3 Nomor 2, 148-154. https:// doi.org/10.24198/jkk.v3i2.7405

Wahyudin, U., \& Setiaman, A. (2019). Karakteristik dan peran kyai dalam sosialisasi perilaku Hidup Bersih dan Sehat di Pesantren. Jurnal Manajemen Komunikasi, Volume 3 N, 123-130. 